Andrews University

Digital Commons @ Andrews University

Faculty Publications

$5-12-1998$

\title{
Major Histocompatibility Complex Class I- And II-Deficient Knock- Out Mice Are Resistant to Primary but Susceptible to Secondary Eimeria Papillata Infections
}

\author{
Marco L. Schito \\ Ontario Veterinary College \\ Bill Chobotar \\ Andrews University, chob@andrews.edu \\ John R. Barta \\ Ontario Veterinary College
}

Follow this and additional works at: https://digitalcommons.andrews.edu/pubs

Part of the Parasitology Commons, and the Zoology Commons

\section{Recommended Citation}

Schito, Marco L.; Chobotar, Bill; and Barta, John R., "Major Histocompatibility Complex Class I- And IIDeficient Knock-Out Mice Are Resistant to Primary but Susceptible to Secondary Eimeria Papillata Infections" (1998). Faculty Publications. 2642.

https://digitalcommons.andrews.edu/pubs/2642

This Article is brought to you for free and open access by Digital Commons @ Andrews University. It has been accepted for inclusion in Faculty Publications by an authorized administrator of Digital Commons @ Andrews University. For more information, please contact repository@andrews.edu. 


\section{Major histocompatibility complex class I- and II-deficient knock-out mice are resistant to primary but susceptible to secondary Eimeria papillata infections}

Received: 6 August 1997/ Accepted: 24 October 1997

\begin{abstract}
Two distinct mechanisms seem to function in reducing oocyst output during Eimeria papillata infections in mice. For naive mice, immunity was afforded by a T-cell-independent gamma-interferon (IFN- $\gamma$ ) response mediated by natural killer (NK) cells. On reinfection, resistance was associated with T-cells and, to a lesser extent, perforin. To determine if antigen presentation with major histocompatibility complex (MHC) molecules was required to control oocyst production by NK cells during primary infection or by T-cells during secondary infection, mutant mice that lacked H2-IA $\beta$ b $\left(\mathrm{A} \beta \mathrm{b}^{-/-}\right)$or $\beta_{2}$-microglobulin $\left(\beta 2 \mathrm{~m}^{-/-}\right)$were used. Since MHC molecules are required for the maturation of $\alpha \beta$ T-cells, $\mathrm{A} \beta \mathrm{b}^{-/-}$and $\beta 2 \mathrm{~m}^{-/-}$mutant mice are also deficient in functional $\alpha \beta^{+} \mathrm{CD}^{+}$or $\alpha \beta^{+} \mathrm{CD} 8^{+} \mathrm{T}$-cells, respectively. As compared with wild-type control mice, oocyst output by mutant mice was not significantly affected during primary infection, suggesting that the ability of NK cells to control parasite replication is not dependent on the expression of MHC molecules. On reinfection, differences were observed for mutant mice as
\end{abstract}

M.L. Schito ${ }^{1} \cdot$ J.R. Barta $(\bowtie)$

Department of Pathobiology,

Ontario Veterinary College,

University of Guelph,

Guelph, Ontario, Canada N1G 2W2

Tel.: + 1-519-824-4120 ext. 4017; Fax: + 1-519-824-5930;

E-mail: jbarta@uoguelph.ca

W. Chobotar

Department of Biology, Andrews University,

Berrien Springs, MI 49104, USA

${ }^{1}$ Present address:

Immunobiology Section,

Laboratory of Parasitic Diseases,

National Institute of Allergy and Infectious Disease,

Building 4, Room 138,

9000 Rockville Pike,

National Institutes of Health,

Bethesda, MD 20892, USA

Tel.: + 1-301-496-4881; Fax: + 1-301-402-0890 compared with controls. $\mathrm{A} \beta \mathrm{b}^{-/-}$mice were found to be more susceptible than $\beta 2 \mathrm{~m}^{-/-}$mice, suggesting that the $\alpha \beta^{+} \mathrm{CD} 4^{+}$T-cell subset plays a greater role in resistance to reinfection than does the $\alpha \beta^{+} \mathrm{CD} 8^{+}$T-cell subset. The mechanism of resistance depends on the immune status of the host and requires the coordinated interaction of both $\alpha \beta^{+}$T-cell subsets for optimal parasite control during subsequent infections.

\section{Introduction}

Eimerian parasites are intestinal intracellular protozoa that can cause severe economic damage for agricultural producers of poultry and cattle who utilize intensive rearing practices. Genetically altered immunodeficient mice provide ideal subjects for the elucidation of immune constituents involved in limiting or exacerbating host-Eimeria interactions. In the murine model, immunity to primary infection appears to be mediated by CD4 ${ }^{+}$T-lymphocytes for E. vermiformis (see Rose et al. 1988), E. pragensis (see Rose et al. 1992), and E. falciformis (see Shi et al. 1989). In the case of E. vermiformis infection, parasite replication is controlled by gammainterferon (IFN- $\gamma$ ), which by itself enhances the host cells' ability to inhibit sporozoite penetration and replication (Rose et al. 1989, 1991). Using monoclonal antibody depletions, natural killer (NK) and $\gamma \delta^{+}$T-cells were shown not to affect E. vermiformis oocyst output (Rose et al. 1996; Smith et al. 1994), which suggests that these cells are not involved in modulating parasite replication. However, E. papillata infections appear to be controlled by a T-cell-independent mechanism during primary infection. Oocyst output was not significantly higher in E. papillata-infected immunodeficient SCID mice as compared with congeneic BALB/c mice (Schito et al. 1996). We have used monoclonal antibody NK1.1-depleted, T/NK-deficient $\left(\mathrm{Tg} \varepsilon 26^{++}\right)$, and IFN- $\gamma$ knock-out mice to show that NK-cell-derived IFN- $\gamma$ mediates immunity in mice infected with $E$. papillata 
(Schito and Barta 1997). Therefore, all murine coccidia examined thus far appear to be controlled by IFN- $\gamma$ during primary infection.

During reinfection, resistance was shown to be mediated by an IFN- $\gamma$-independent mechanism for E. vermiformis (see Rose et al. 1989) and E. papillata (Schito and Barta 1997). Immunity to E. papillata was, in part, mediated by perforin during secondary infection (Schito and Barta 1997), which suggests that CD ${ }^{+} \mathrm{T}$ cells may play a role. Likewise, $\mathrm{CD} 8^{+} \mathrm{T}$-cells were partially responsible for resistance to E. vermiformis and E. pragensis in reinfected mice (Rose et al. 1992).

In the present study we examined oocyst output in $\beta 2 \mathrm{~m}^{-1-}$ and $\mathrm{A} \beta \mathrm{b}^{-/-}$knock-out mice in comparison with wild-type control mice during primary and secondary E. papillata infections. These genes are essential for the assembly, surface expression, and antigen presentation of major histocompatibility complex (MHC) class I or II molecules (Cosgrove et al. 1991, Zijlstra et al. 1990). Most $\alpha \beta$ T-lymphocytes require MHC molecules to complete their thymic maturation. Thus, mice deficient of MHC class I or II molecules are virtually devoid of functional $\mathrm{CD}^{+}{ }^{+}$or $\mathrm{CD} 4^{+} \alpha \beta$ T-lymphocytes, respectively (Grusby et al. 1991, Koller et al. 1990). Our results suggest that MHC antigen presentation is not involved in controlling immunity to E. papillata during primary infection but is involved during secondary infection. It appears that $\alpha \beta^{+} \mathrm{CD} 4^{+}$T-cells are more critical than $\alpha \beta^{+} \mathrm{CD} 8^{+} \mathrm{T}$-cells during reinfection since MHC class II-deficient mice were more susceptible than MHC class I-deficient mice.

\section{Materials and methods}

Animals

Male mice, purchased from Taconic (Germantown, N.Y.), were used at 6 weeks of age and kept in barrier-isolated facilities within microisolator cages. Six mice of each of the following strains were used throughout the experiment: MHC class I knock-out (C57BL/ 6GphTacfBR-[KO] $\beta$ 2m N5), MHC class I wild-type control (C57BL/6GphTacfBR-[KO] $\beta$ 2m N6), MHC class II knock-out (C57BL/6TacfBR-[KO]A ${ }_{\beta}{ }^{b} \mathrm{~N} 5$ ), and MHC class II wild-type control (C57BL/6TacfBR-[KO]A $\left.{ }_{\beta}{ }^{\mathrm{b}} \mathrm{N} 6\right)$.

Parasite inoculation, collection, and enumeration

Mice were inoculated orally with $10^{3}$ surface-sterilized sporulated oocysts of Eimeria papillata in $10 \mu \mathrm{l}$ saline using a $20-\mu \mathrm{l}$ micropipettor as previously described (Schito et al. 1996). Fecal samples from individual mice were collected once every $24 \mathrm{~h}$ until oocyst shedding could no longer be detected. During patent infections, cages were changed daily to eliminate reinfection. Oocysts were counted using McMaster counting chambers, and the results are expressed as numbers of oocysts per gram wet feces as previously described (Schito et al. 1996). Mice were experimentally reinfected at 30 days postinfection (p.i.) for secondary infections and fecal samples were collected as described above. Student's $t$-test was used to determine if oocyst output in knock-out mice were significantly different from that in wild-type control mice $(P<0.05)$.

\section{Results}

Antigen presentation via MHC is not involved in immunity to primary infection

The involvement of T-lymphocytes in immunity to primary infection has been demonstrated for a variety of Eimeria species in the mouse (Rose et al. 1985), rat (Rose and Hesketh 1979), and chicken (Lillehoj 1987). Immunity against primary infection with $E$. papillata was not significantly affected in SCID mice as compared with congeneic BALB/c mice (Schito et al. 1996), which suggests that $\mathrm{T}$ - and/or B-lymphocytes are not involved in mediating immunity during primary infection. Antibodies are probably not involved in immunity to E. papillata because of the parasites' intracellular location and short life cycle (ca. 4 days). Oocyst output was found to be significantly higher in NK-cell-depleted (NK1.1), T- and NK-cell-deficient (Tg \& 26 $\left.{ }^{++}\right)$, and IFN- $\gamma$ knock-out mice, suggesting that oocyst output is controlled by the presence of NK cells and the production of IFN- $\gamma$ (Schito and Barta 1997).

During primary infection, oocyst output was not significantly affected in either class I- or class II-deficient mice as compared with controls (Fig. 1A,C), confirming that neither $\alpha \beta^{+} \mathrm{CD} 4^{+}$nor $\alpha \beta^{+} \mathrm{CD} 8^{+}$T-cells are involved in mediating immunity to $E$. papillata infection in naive mice. The inability of MHC class I knock-out mice to present antigens by $\beta 2 \mathrm{~m}$-dependent classic and nonclassic molecules did not affect the ability of NK cells to mediate immunity.

Recent studies suggest that NK cells exhibit specificity for MHC class I molecules when interacting with target cells (Hoglund et al. 1997; Raulet 1996). Ly49 receptors expressed by NK cells mediate the interactions against MHC class I target cells and function as cytotoxic inhibitory signals (Nakamura et al. 1997; Salcedo et al. 1997). Therefore, the balance between activation and inhibitory signals received by NK cells determines NK-cell lytic activity. MHC class I knock-out mice are incapable of presenting antigens by $\beta 2 \mathrm{~m}$-dependent classic and nonclassic molecules. Oocyst output was not affected in $\beta 2 \mathrm{~m}$ knock-out mice as compared with wild-type control mice, which suggests that disruption of this pathway did not affect the ability of NK cells to mediate immunity.

\section{Role of MHC class I and CD8 T-lymphocytes} during secondary infection

Previously, we observed that perforin knock-out mice were more susceptible to secondary E. papillata infection but that this mechanism was only partially responsible for resistance (Schito and Barta 1997). We hypothesized that $\mathrm{CD}^{+}$T-cells might mediate immunity by a perforin-dependent mechanism because resistance is T-cell-dependent. Our results confirm that $\alpha \beta^{+} \mathrm{CD} 8^{+}$ $\mathrm{T}$-cells play a small but significant role in immunity to 
Fig. 1A-D Primary and secondary induced infections in knock-out and control mice using $10^{3}$ Eimeria papillata oocysts. A Oocyst output during primary infections in $\beta 2 \mathrm{~m}^{-/}$

$(\boldsymbol{\Delta})$ and wild-type control $(\triangle)$ mice. B Oocyst output during secondary infections in $\beta 2 \mathrm{~m}^{-9}$ $(\diamond)$ and wild-type control $(\diamond)$ mice. C Oocyst output during primary infections in $\mathrm{A} \beta \mathrm{b}^{-/-}$

$(\bigcirc)$ and wild-type control $(\bigcirc)$ mice. D Oocyst output during secondary infection in $\mathrm{A} \beta \mathrm{b}^{-/-}$ (匹) and wild-type control ( $\square$ ) mice. Data represents values for the mean oocyst output of 6 mice \pm SE. Statistically significant differences $(P<0.05)$ between knock-out and control mice are indicated by an asterisk
Primary
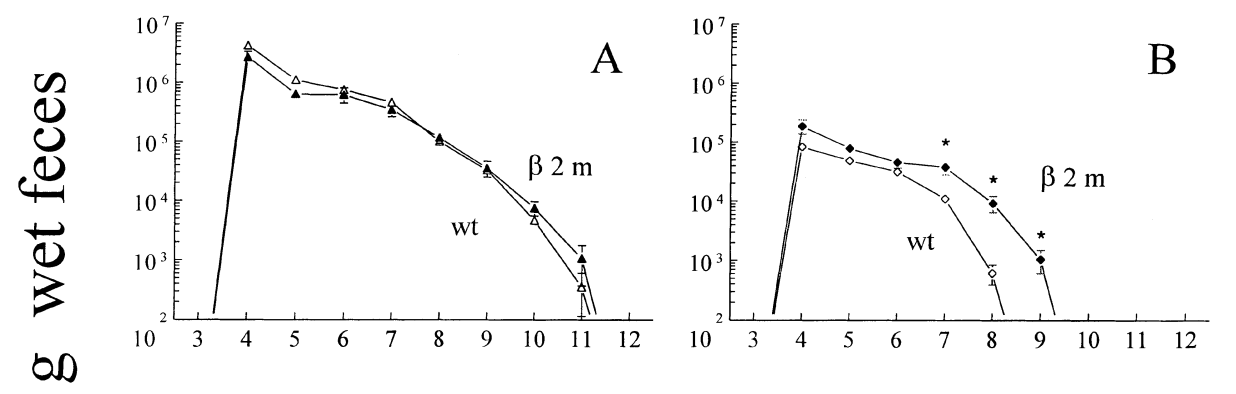

$\frac{3}{3}$
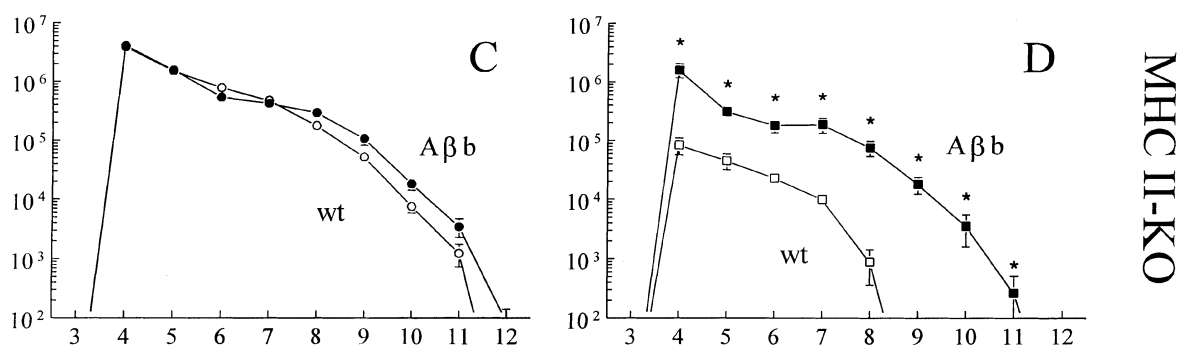

\section{Days Postinoculation}

reinfection (Fig. 1B). Furthermore, oocyst production in $\beta 2 \mathrm{~m}$-deficient mice appears to be similar to that in perforin knock-out mice, which strengthens the notion that immunity to E. papillata during secondary infection is mediated in part by a perforin-dependent mechanism via $\alpha \beta^{+} \mathrm{CD} 8^{+}$T-lymphocytes.

Role of MHC class II and CD4 T-lymphocytes during secondary infection

Resistance to E. papillata during secondary infection is mediated by T-cells via an IFN- $\gamma$-independent mechanism (Schito and Barta 1997). As compared with primary infections, mesenteric lymph-node lymphocytes stimulated with concanavalin A (Con-A) or parasite antigens secreted interleukin 2 (IL-2) at higher concentrations and at earlier time points during secondary infections (Schito et al. 1998). For MHC class II-deficient mice, oocyst output during secondary infection was significantly higher at all time points as compared with wild-type control mice (Fig. 1D). This result suggests that antigen presentation by MHC class II molecules and, therefore, $\alpha \beta^{+} \mathrm{CD} 4^{+}$T-lymphocytes, constitutes a major event in the suppression of parasite proliferation during secondary infection.

\section{Discussion}

The evidence provided from these experiments supports the view that T- and B-cells do not play a role in re- ducing oocyst output during primary infection. The ability of $\beta 2 \mathrm{~m}^{-/-}$and $\mathrm{A} \beta \mathrm{b}^{-/-}$mutant mice to control oocyst production correlates well with previous observations that implicate nonspecific effector cells, including neutrophils and NK cells, in the mediation of protective primary immune responses (Schito and Barta 1997).

Mice reinfected with either Eimeria vermiformis, E. pragensis, or E. papillata require T-lymphocytes to reduce oocyst production significantly (Rose et al. 1992; Schito et al. 1996). Although $\beta 2 \mathrm{~m}^{-/-}$and $\mathrm{A} \beta \mathrm{b}^{-/-}$mutant mice are devoid of $\alpha \beta^{+}$T-cell subsets, the development and phenotype of $\gamma \delta^{+}$T-cells present in lymphoid and mucosal tissues of these mice are the same as those of wild-type control mice (Bigby et al. 1993; Raulet 1994; Schleussner and Ceredig 1993). However, oocyst output in E. vermiformis-infected mice made deficient in $\gamma \delta^{+}$ T-cells by antibody depletion (Rose et al. 1996) or gene ablation (Roberts et al. 1996) is not significantly affected as compared with that in control mice. Higher numbers of intestinal $\alpha \beta^{+}$T-cells were seen in BALB/c mice reinfected with $E$. papillata as compared with control mice, whereas intestinal $\gamma \delta^{+}$T-cells were not significantly affected (Schito et al. 1998). Although possible, it is unlikely that the outcomes in this study were effected by $\gamma \delta^{+}$T-cells.

We have previously suggested that $\mathrm{CD} 8^{+} \mathrm{T}$-cells are capable of killing target cells by an IL-2, perforindependent mechanism in mice reinfected with $E$. papillata (Schito and Barta 1997). The ability of $\beta 2 \mathrm{~m}^{--}$ mice to resist reinfection to a greater extent than other immunodeficient mice may be due to compensatory 
mechanisms. For example, T-cells expressing CD8 alpha homodimers are present in the intestinal intraepithelial compartments of $\beta 2 \mathrm{~m}^{-/-}$mice (Fujiura et al. 1996; Neuhaus et al. 1995) and are functional with respect to cytokine production and cytolytic activities (Emoto et al. 1996).

As compared with wild-type controls, $\mathrm{A} \beta \mathrm{b}^{-/-}$mutant mice are more susceptible to secondary E. papillata infection. Using $A \beta \mathrm{b}^{-/-}$mutant mice, oocyst output was consistently lower throughout secondary infections (on average by $0.5 \mathrm{log}$ ) in comparison with oocyst output during primary infections. Although a naive group of $\mathrm{A} \beta \mathrm{b}^{--}$mutant mice were not run in parallel during secondary infections, we believe that the difference is due to $\alpha \beta^{+} \mathrm{CD} 8^{+}$T-cells. For $\alpha \beta^{+} \mathrm{CD} 8^{+}$T-cells to perform their cytotoxic activities in $\mathrm{A} \beta \mathrm{b}^{-/-}$mutant mice, an alternative source of IL-2 is required because these mice lack functional $\alpha \beta^{+} \mathrm{CD} 4^{+}$T-cells. Denkers et al. (1996) have recently shown that $\mathrm{CD} 4^{+} \mathrm{NK} 1.1^{+}$lymphocytes can produce IL-2 for the generation of cytotoxic CD8 ${ }^{+}$ T-cells in MHC class II knock-out mice.

In summary, primary E. papillata infections are not affected by the lack of MHC class I or class II molecules, indicating that NK cells can control oocyst output in the absence of classic antigen presentation. When reinfected, $\mathrm{A} \beta \mathrm{b}^{-/-}$mutant mice are more susceptible than $\beta 2 \mathrm{~m}^{-/-}$ mutant mice as compared with wild-type controls. Therefore, immunity to E. papillata is not mediated by $\alpha \beta^{+} \mathrm{CD} 4^{+}$or $\alpha \beta^{+} \mathrm{CD} 8^{+}$T-cells during primary infection but is mediated during secondary infection by $\alpha \beta^{+} \mathrm{CD} 4^{+}$T-cells, with $\alpha \beta^{+} \mathrm{CD} 8^{+} \mathrm{T}$-cells playing a minor role. Although the data support a multifactorial immune response for protection, the cellular phenotypes responsible differ, depending on the parasite species and the immune status of the host.

Acknowledgements This work received funding from the Natural Sciences and Engineering Research Council of Canada (OGP0106453) and from the Ontario Ministry of Agriculture, Food, and Rural Affairs Research Program (to J. R. B.). Additional support was provided by Andrews University. We thank Dr. M.A. Fernando, Dr. D. Martin, R. Carreno, S. Lee, S. Beattie, S. Kopko, K. Strickler, and M. Tahir for constructive criticism.

\section{References}

Bigby M, Markowitz JS, Bleicher PA, Grusby MJ, Simha S, Siebrecht M, Wagner M, Nagler-Anderson C, Glimcher LH (1993) Most gamma delta T cells develop normally in the absence of MHC class II molecules. J Immunol 151: 44654475

Cosgrove D, Gray D, Dierich A, Kaufman J, Lemeur M, Benoist C, Mathis D (1991) Mice lacking MHC class II molecules. Cell 66: $1051-1066$

Denkers EY, Scharton-Kersten T, Barbieri S, Caspar P, Sher A (1996) A role for CD4 $4^{+} \mathrm{NK} 1.1^{+} \mathrm{T}$ lymphocytes as major histocompatibility complex class II independent helper cells in the generation of $\mathrm{CD} 8^{+}$effector function against intracellular infection. J Exp Med 184: 131-139
Emoto M, Neuhaus O, Emoto Y, Kaufmann SHE (1996) Influence of $\beta_{2}$-microglobulin expression on gamma interferon secretion and target cell lysis by intraepithelial lymphocytes during intestinal Listeria monocytogenes infection. Infect Immun 64: $569-575$

Fujiura Y, Kawaguchi M, Kondo Y, Obana S, Yamamoto H, Nanno M, Ishikawa H (1996) Development of CD8 $\alpha \alpha^{+}$intestinal intraepithelial $\mathrm{T}$ cells in $\beta_{2}$-microglobulin- and/or TAP1-deficient mice. J Immunol 156: 2710-2715

Grusby MJ, Johnson RS, Papaioannou VE, Giimcher LH (1991) Depletion of $\mathrm{CD}^{+}{ }^{+} \mathrm{T}$ cells in major histocompatibility complex class II-deficient mice. Science 253: 1417-1420

Hoglund P, Sundback J, Olsson-Alheim MY, Johansson M, Salcedo M, Ohlen C, Ljunggren HG, Sentman CL, Karre K (1997) Host MHC class I gene control of NK-cell specificity in the mouse. Immunol Rev 155: 11-28

Koller BH, Marrack P, Kappler JW, Smithies O (1990) Normal development of mice deficient in beta $2 \mathrm{M}$ MHC class I proteins, and $\mathrm{CD}{ }^{+} \mathrm{T}$ cells. Science 248: $1227-1230$

Lillehoj HS (1987) Effects of immunosuppression on avian coccidiosis. Cyclosporin A but not hormonal bursectomy abrogates host protective immunity. Infect Immun 55: 1616-1621

Nakamura MC, Niemi EC, Fisher MJ, Shultz LD, Seaman WE, Ryan JC (1997) Mouse Ly-49A interrupts early signaling events in natural killer cell cytotoxicity and functionally associates with the SHP-1 tyrosine phosphatase. J Exp Med 185: 673-684

Neuhaus O, Emoto M, Blum C, Yamamoto S, Kaufmann SHE (1995) Control of thymus-independent intestinal intraepithelial lymphocytes by $\beta 2$-microglobulin. Eur J Immunol 25: 2332 2339

Raulet DH (1994) MHC class I-deficient mice. Adv Immunol 55: 381-421

Raulet DH (1996) Recognition events that inhibit and activate natural killer cells. Curr Opin Immunol 8: 372-377

Roberts SJ, Smith AL, West AB, Wen L, Findley RC, Owen MJ, Hayday AC (1996) T-cell $\alpha \beta^{+}$and $\gamma \delta^{+}$deficient mice display abnormal but distinct phenotypes toward a natural, widespread infection of the intestinal epithelium. Proc Natl Acad Sci USA 93: 11774-11779

Rose ME, Hesketh P (1979) Immunity to coccidiosis: T-lymphocyte- or B-lymphocyte, deficient animals. Infect Immun 26: 630-637

Rose ME, Wakelin D, Hesketh P (1985) Susceptibility to coccidiosis: contrasting course of primary infections with Eimeria vermiformis in $\mathrm{BALB} / \mathrm{c}$ and $\mathrm{C} 57 / \mathrm{BL} / 6$ mice is based on immune responses. Parasite Immunol 7: 557-566.

Rose ME, Joysey HS, Hesketh P, Grencis RK, Wakelin D (1988) Mediation of immunity to Eimeria vermiformis in mice by $\mathrm{L} 3 \mathrm{~T} 4^{+} \mathrm{T}$ cells. Infect Immun 56: 1760-1765

Rose ME, Wakelin D, Hesketh P (1989) Gamma interferon controls Eimeria vermiformis primary infection in $\mathrm{BALB} / \mathrm{c}$ mice. Infect Immun 57: 1599-1603

Rose ME, Smith AL, Wakelin D (1991) Gamma interferon-mediated inhibition of Eimeria vermiformis growth in cultured fibroblasts and epithelial cells. Infect Immun 59: 580-586

Rose ME, Hesketh P, Wakelin D (1992) Immune control of murine coccidiosis: $\mathrm{CD}^{+}$and $\mathrm{CD} 8^{+} \mathrm{T}$ lymphocytes contribute differentially in resistance to primary and secondary infections. Parasitology 105: 349-354

Rose ME, Hesketh P, Rothwell L, Gramzinski R (1996) T-cell receptor lymphocytes and Eimeria vermiformis infection. Infect Immun 64: 4854-4858

Salcedo M, Diehl AD, Olsson-Alheim MY, Sundback J, Van Kaer L, Karre K, Ljunggren HG (1997) Altered expression of Ly49 inhibitory receptors on natural killer cells from MHC class I-deficient mice. J Immunol 158: 3174-3180

Schito ML, Barta JR (1997) Non-specific immune responses and mechanisms of resistance to infections with Eimeria papillata in mice. Infect Immun 65: 3165-3170

Schito ML, Barta JR, Chobotar B (1996) Comparison of four murine Eimeria species in immunocompetent and immunodeficient mice. J Parasitol 82: 255-262 
Schito ML, Chobotar B, Barta JR (1998) Cellular dynamics and cytokine responses in BALB/c mice infected with Eimeria papillata during primary and secondary infections. J Parasitol 84 (in press)

Schleussner C, Ceredig R (1993) Analysis of intraepithelial lymphocytes from major histocompatibility complex (MHC)-deficient mice: no evidence for a role of MHC class II antigens in the positive selection of V delta $4+$ gamma delta $\mathrm{T}$ cells. Eur $\mathbf{J}$ Immunol 23: 1615-1622
Shi Y, Mahrt JL, Mogil RJ (1989) Kinetics of murine delayed-type hypersensitivity response to Eimeria falciformis (Apicomplexa: Eimeriidae). Infect Immun 57: 146-151

Smith AL, Rose ME, Wakelin D (1994) The role of natural killer cells in resistance to coccidiosis: investigations in a murine model. Clin Exp Immunol 97: 273-279

Zijlstra M, Bix M, Simister NE, Loring JM, Raulet DH, Jaenisch R (1990) $\beta 2$-Microglobulin-deficient mice lack CD4-CD8 ${ }^{+}$cytolytic T cells. Nature 344: 742-746 